olject-glasees would probably give matchless sular phologianìs. 'The i 20 feet has 6 inches aperture, and would give a solar pic. ture 13.4 inches diameter. R.

\section{The Potato Disease}

1 AM afraid $i$ cannot regard the letter of your anonymious correspondent "Inquirer" as written in altogether grood faith. He first misrepresents what 1 stated in my letter of Nov. 20, which hic professes to quote, and then proceeds to ask me a question which, if he had even glanced at my letter, he would have seen was alrcady answered.

If $I$ beg your indulgence for some further remarks suggested by "Inquirer's" letter, I hope that they will be the last it will be necessary to make.

The number of NATURE for Nov. 19 gave what purported to be an account of the "Report of the Potato Disease Committee of the Royal Agricultural Society." It contained the following passage :- "Pror. de I3ary has worked out the scientific questions that occur as to the origin of the disease. It is owing to a fungus (Peronospora infestanss), which attacks the leaves first, and after absorbing the nutritnent of them, titilises the petiole, arid thus reaches the tubes" (sic). It appeared to me, as it did to others, that the only meaning which could be attributed to this was that we owed to Prof. de Bary all the knowlerlge we at present posscss with regard to the disease.

I therefore thought it fair to point out in the following number "that all this and a good deal more was ascertained by the Rev. M. I. Berkcley in this country, and by Montagne in France, and published by the former in a paper contributed to the first volume of the Journal of the Ilorticultural Society in $1846 . "$ It is almost incredible that anyone with my letter before him should say that I had asscrted "the discor'wy" by the Rev. M. J. Berkeley of the fact that the potato disease was due to the attacks of a parasitic fungus," and should proceed to ask me for "a morc evict refirence to the records."

The potato disease appeared on the Continent a few years belore it worked such ravages in the British Isles. The mould had been detected upon the foliage in France and Bel inm, lut opinion was divided as to the part it reaily plinged. And we have Mr. Berkeley's authority for asserting that even Montarne, to whom "Inquirer" attributes the discovery that the potao disease was clue to the attacks of a parasitic fungus, did not support the "fungal theory."

In this country Mr. Berkeley maintained it almost" singlehanded against men of such weight as Iindley and Playfair. Ili: paper, which appeared in the Yorticultural Socicty's Journal in November 1845 (the whole volume is dated 18.46 ), really, however, settled the matter.

It is perfecily easy to trace what Mr. Berkeley dil by referring to the horticultural papers of the time. Thus, he wrote to the Giarden'r's Chronicle, Aitgust 30, IS45 (0. 593): "The malady by which potatoes are so generally affected this year, both in this country and on the Continent, does not appear to prevail in this neighbourhood. . . I I lave this morning received from Dr. Montagne, of Paris, some leaves affected will the mildew. . . The parasite of the potato does not appear to have been olserved before by systemalists." On Sept. 6 (p, 608): "You will be interested to learn that the mould upon the potatoes which you sent me is identical with that upon the leaves, and the same with what I have received from Paris. It appears, then, that the decay of the huthers is produced by the same canse wothich afficts the liarisis, viz, by the growth of a mould whose development has been prumoted by excessive wet." On Sept. 20 (p. 640): "In every case I find the But"1tis infestans [now" called Pironuspora infostans] preceding the work of destruction."

All this is given wilh very full details hy Mr. Berkeley in his later paper. What I wish, however, particularly to puint out is that the aclmirable observation (contained in the words I have italicised) of the iclentily of the fungus which attacks the foliage with that which destroys the potatoes was made absolutcly independently by Mr. Berkicley. Morren appears to have made it about the same time. It is a sufficient proof of the estimation in which his investigations were held at the time, that Montigne relinquished the intention of writing upon the subject, and transmitted his materials to Mr. Berkeley, by whom the use of them is duly acknowledged.

W. T. Thiselton Dyer

\section{Mr. Cuttell and Section Cutting}

TN your number of NATURE just issued you have given an extract from the annual arddress of the President of the Royal
Society, iti whicti reference is made to my labour of section cutting. It is perfectly true that I have prepared more thian a thousand sections of coal plants, but it woitl be unfair to i very efficient auxiliary not to mention the help he has afforded me in this work. I require many sections of a much larger size than my machinery is capable of cutting, and these have been prepared for me by the skilled hands of Mir. Cuttell, of New Compton Street; London.

In each of two instances, also, I am indebted to the same experienced Japidary for obtaining three sections out of small but precious fragments, not more than from three-sixteenths to a quarter of an inch in thickness. I am anxinus to recognise these services, and not to monopolise Mr. Cuttell's share of the credit for the labours to which Dr. IYooker's report refers so kindly.

Fallowficld, Manches'er, Dec. 24

$$
\text { W. C. WILLIAMASON }
$$

\section{Snakes and Frogs}

IN reading the letter of your correspondent, $\mathrm{Mr}$. Mott, on the cry of the frog, it struck me as curious that there should be resem. blanices which people in countries wide apart should pitch on the same phizse to indicate. Now, there could not be a better way of conveying a sound which frequently greets one's ears in the country in Bencal during the rains, than that which your correspondent makes use of, "the cry of a new-born infant." Few residen's in the country here, we take it, who have lived anywhere near jungle, will have failed to hear, and that tolerab'y frequent, the unspeakably plaintive wail which indicates that the remorseless ophidian has seized his prey, and that deglutition has commenced. If one be tolerably quick he may, as I have frequently done, guide himself to the very spot by the sound of the frog, and the snake will then, in his alarm and anxiety to escape, frequently let the frog go, though he as often slides off with it protruding from his mouth. We have the batrachians in great force here, and of all sizes and noises, from the great swamp frog which, as soon as the lands are drenched in the heavy rainstorms of May, commences its nocturnal bellowing, down to the bronze tree frog with gilt eyebrows that keeps up its metallic tink.

The frog is connected with some of the reltgious ceremonies of the country; and one may see here, as well as in Assam, the curious custom of "bathing the frogs" in a cage. This is done in time of drought to propitiate the rain god. Grain is sometimes put out on a mat to sun, and to prevent the crows from makingr away with it, a frog is tied by the leg to a stake; his constant hopping about acts as a deterrent to the crow. Hence the native proverb denoting vicarinus and anmerited suffering, "The crow steals the gra: 11 , and the string is round the l-r of the fio:"."

Budderpore, Eastern Rengal

\section{THE ANDERSON SCHOOL OF NATLRAL TISTTORY}

MOST of our readers, no doubt, have heard of the IV School of Natural History established by the late Prof. Agassiz, in conjunction with some of his American friends, shortly before his lamented decease. The first report of the trustees of this institution, which has lately been received in this country, sives a fuller account of its foundation and subsequent progress than has yet reached us.

The plan of the school was first put forward by its orizinator in a circular issued in December 1872 , from the Museum of Comparative Zoology at Cambridge, U.S.A. It was proposed that courses of instructive lectures in various branches of natural history should be delivered by the sea-side, at Nantucket-an American bathingplace-during the summer months, by Agassiz himself, and by other nafuralists belonging either to the same institution; or to other scientific establishments in the United States, who had combined together to assist him: The object of these courses was chiefly for the benefit of teachers proposing to introduce the study of natural history into their schools, and for such students as were preparing to become teachers. Besides the lectures it 